\title{
CONFLICT OF LAWS - FOREIGN TORT - NOT JUSTIFIABLE BY THE LEX LOCI DELICTI - RESIDENCE OF DEFENDANT - INTERPROVINCIAL COMITY - JUDICIAL CREATIVITY
}

\section{J.G. CASTEL•}

The conflict of laws rule applicable in foreign torts contains two conditions. First, the wrong must be actionable under the law of the forum. Second, the wrong must not be justifiable by the law of the place where the tort occurred. Professor Castel welcomes a recent decision of the Ontario Court of Appeal further refining the second condition of the rule. However, he argues that the decision of the Court of Appeal is actually a disguised attempt to adopt the doctrine of the proper law of the tort dependent upon establishing which jurisdiction has the most significant relationship with the tort. In his call for reform Professor Castel drafis a new foreign torts rule with a proper law of the tort exception that is only to be applied in special circumstances.
La règle du conflit de lois applicable aux délits étrangers contient deux conditions. Premièrement, le délit ou quasi-délit doit ouvrir droit à une poursuite aux termes de la loi du for. Deuxiemement, le délit ne doit pas être défendable par la loi de l'endroit où il s'est produit. Le Professeur Castel se déclare en faveur d'une décision récente de la Cour d'appel de l'Ontario qui raffine plus avant cette deuxieme condition. Il avance néanmoins que la décision de la Cour d'appel constiuce en fait une tentative voilée d'adopter la doctrine du droit de la responsabilité civile applicable après avoir établi quelle autorité législative entretient le lien le plus significatif avec le délit. Dans son appel d la réforme, le professeur Castel propose une nouvelle règle des délits étrangers contenant une dérogation au droit de la responsabilité civile compétente qui ne peut s'appliquer que dans des circonstances spéciales.

In Grimes v. Cloutier and Cloutier' the Ontario Court of Appeal, in a burst of judicial creativity, reconsidered the second condition in Phillips v. Eyre ${ }^{2}$ as interpreted by Machado v. Fontes ${ }^{3}$ and applied by the Supreme Court of Canada in McLean v. Pettigrew. ${ }^{4}$ The new approach adopted by the Court of Appeal alleviates some of the shortcomings of the rule in an area where legislative or judicial reform has been long overdue. Before examining Grimes v. Cloutier and Cloutier, it is proper to review very briefly the general common law conflict of laws rule applicable to foreign torts which was enunciated by Willes J. in Phillips v. Eyre more than a century ago: ${ }^{5}$

"As a general rule, in order to found a suit in England for a wrong alleged to have been committed abroad, two conditions must be fulfilled. First, the wrong must be of such a character that it would have been actionable if committed in England. . . . Secondly, the act must not have been justifiable by the law of the place where it was done."

In the common law world, much difference of opinion has arisen with respect to the interpretation and application of this general rule.

There is a substantial body of judicial opinion which holds that both conditions determine the jurisdiction of the courts over the cause of action, i.e. foreign torts. ${ }^{6}$ Once they have been met, the lex fori applies to questions of substance and procedure. The primacy given to the lex fori encourages forum shopping although it may be controlled by the doctrine of forum non con-

* Distinguished Research Professor, Osgoode Hall Law School, York University.

1. (1989), 69 O.R. (2d) 641 (C.A.).

2. (1870), L.R. 6 Q.B. 1.

3. [1897] 2 Q.B. 231 (C.A.).

4. [1945] S.C.R. 62.

5. Supra, note 2 at $28-29$.

6. See, for example, Gagnon v. Lecavalier (1967), 63 D.L.R. (2d) 12 at 13. 
veniens. Questions of substance should not be determined by the lex fori in its domestic sense especially when that law has no connection with the forum. To interpret the general rule as jurisdictional in nature is not satisfactory as it often leads to unjust results. This is why, in Canada, most courts have considered the rule in Phillips v. Eyre to be a true double-barrelled choice of law rule of the lex fori. ${ }^{7}$

The first condition of the rule that a wrong must be of such character that it would have been actionable if committed in England has not given rise to much controversy. It is a parochial rule that encourages forum shopping and may lead to injustice. The claim must have arisen in circumstances that if they had occurred in the forum, a cause of action would have arisen entitling the plaintiff to enforce against the defendant a civil liability of the kind which the plaintiff claims to enforce. In other words, civil liability must exist under the lex fori.

It is with respect to the meaning of the second condition of the rule, i.e. the act must not have been justifiable by the law of the place where it was done, that much confusion still exists today due to many divergent interpretations. The issue is whether something other than civil liability is sufficient to render an act not justifiable.

In Canada, the Supreme Court has adopted the interpretation given to that condition by the English Court of Appeal in Machado v. Fontes ${ }^{8}$ that 'not justifiable' means not legally innocent. Thus, criminal liability is sufficient to render an act not justifiable even though it does not give rise to any civil actionability or liability. Machado v. Fontes has been much criticized and was overruled by a majority of the House of Lords in Chaplin v. Boys ${ }^{9}$ which held that the act is not justifiable only if it is civilly actionable under the lex loci delicti. The concept of civil actionability is also subject to several interpretations. It could mean a) actionability by the lex loci delicti whether or not damages can be recovered, ${ }^{10}$ for instance where the act creates a cause of action but there exists a complete defence which precludes civil liability from arising or b) some civil liability under the lex loci delicti even though some of the damages claimed by the plaintiff cannot be recovered under that law, " or c) civil liability in accordance with the lex loci delicti including the extent of such liability. Here, the provisions of the lex loci delicti denying, limiting or qualifying the recovery of damages must be taken into consideration before determining whether the act is not justifiable by that law. The question is not whether the act was innocent but whether civil liability existed in respect of the relevant claim as between the actual parties under the lex loci delicti of the

7. J.G. Castel, Canadian Conflict of Laws (2d ed., 1986), at para. 469, and generally see P. Bates, "Foreign Torts: The Canadian Choice of Law Rule" (1987) 8 Advocate Q. 397.

8. [1897] 2 Q.B. 231 (C.A.). Lopes and Rigby J.J. considered that the act complained of must not be "innocent" in the country where it was done and that if the act was contrary in any respect to the law of that country, though giving rise to no civil liability there, it was not "justifiable" for the purpose of the second condition. Can. Nat'l SS Co. Ltd. v. Watson, [1939] S.C.R. I1; McLean v. Pettigrew, supra, note 4.

9. [1971] A.C. 356.

10. Harley v. Venn (1967), 10 F.L.R. 151 (Australia).

11. This was the situation in Chaplin v. Boys, supra, note 9. 
kind sought to be imposed under that law. ${ }^{12}$ This interpretation is consistent with the vested rights theory propounded by Willes J. in Phillips v. Eyre. ${ }^{13}$ It also achieves the objective of certainty and, in the case of interprovincial torts, gives recognition to the laws in force at the place of tort. An individual should not be able to claim in the forum in respect of a matter for which civil liability does not exist or is excluded under the law of the place where the wrong was committed.

In Chaplin v. Boys, the House of Lords did not replace the rule in Phillips v. Eyre by the doctrine of the proper law of a tort. ${ }^{14}$ However, Lords Hodson and Wilberforce introduced that doctrine as an exception in the name of flexibility in order to achieve individual justice in cases where with respect to a particular issue, the place of tort has little interest in seeing its law applied due to lack of other proper connections. ${ }^{15}$ This exception finds its justification in the language used by Willes J. in Phillips v. Eyre when he said " [a]s a general rule" ${ }^{16}$ The exception to the general rule should discourage forum shopping. It does not confer an unfettered judicial discretion away from the lex loci delicti or the lex fori, enabling the general rule to be ignored in arbitrary fashion, as there must be a sufficient justification to apply it.

In Canada, the courts are still trying to find ways to escape the clutches of Machado v. Fontes. Thus, in Grimes v. Cloutier and Cloutier, ${ }^{17}$ the respondent, a resident of Ontario, while riding as a passenger in an automobile registered and insured in Ontario and driven by an Ontario resident, sustained personal injuries as a result of a collision in Quebec with an automobile registered and insured in that province driven by the first appellant and owned by the second appellant, both residents of Quebec. The first appellant had been found guilty of driving in breach of the Quebec Highway Code ${ }^{18}$ at the time of the collision. The respondent had received benefits in full satisfaction of all amounts payable to her in accordance with the provisions of the Quebec Automobile Insurance Act, ${ }^{19}$ which as a result of an Agreement between Quebec and Ontario ${ }^{20}$ were part of the Ontario Standard Automobile Policy. ${ }^{21}$ In addition, she brought an action for full common law damages in Ontario against the two Quebec residents in order to obtain more than that which was provided by the Quebec insurance scheme, which proscribed civil actionability.

12. Lord Wilberforce in Chaplin v. Boys, ibid. at 389. It is the relevant claim as between the actual parties which must be looked at, and not whether such a claim would in theory be actionable. Per Dunn L.J. in Armagas Lrd. v. Mundogas S.A., [1986] I A.C. 717 at 753 (C.A.); also Goff L.J. at 740; and Breavington v. Godleman (1988), 62 A.L.J.R. 447 (Australia H.C.).

13. See (1870), L.R. 6 Q.B. 1 at 28.

14. For the proper law of a tort see Restatement of the Law Second, Conflict of Laws (1971), ss. 145-146.

15. Supra, note 9. at 377-378, 380, 391-392.

16. Supra, note 2 at $28-29$.

17. Supra, note 1.

18. R.S.Q. 1977 , c. C-24, s. 83.

19. L.Q. 1977 , c. 68 , esp. ss. 4 and 8.

20. Dec. 27, 1978.

21. Insurance Act. R.S.O., 1980, c. 218 as am. by Reg. 1004-78. 
The trial judge found for the respondent as he refused to distinguish the facts of this case from those of McLean v. Pettigrew. On appeal, the Ontario Court of Appeal stated the issue as follows:"22 "The substantial issue in this appeal is whether the judgment of the Supreme Court of Canada in McLean v. Pettigrew, [1945] S.C.R. 62, [1945] 2 D.L.R. 65 requires us to uphold the judgment against the appellants notwithstanding that (1) they are Quebec residents, (2) the accident occurred in the Province of Quebec and, (3) under Quebec law they are not civilly liable." Although the court was prepared to distinguish McLean v. Pettigrew on the facts, it was not prepared to give an entirely new interpretation to the second rule in Phillips v. Eyre or to adopt the doctrine of the proper law of a tort either as a general rule for foreign torts or as an exception to Phillips v. Eyre on the ground that: "Whatever weakness there may be in the interpretative reasoning in Machado v. Fontes, a countervailing consideration should also be noted: as a matter of policy an inflexible rule that the absence of civil liability in the place where the alleged tort took place is a valid defence can, in some cases lead to an unjust result." 23

In McLean v. Pettigrew $w^{24}$ the accident occurred in Ontario. The plaintiff was a gratuitous passenger in the automobile driven and owned by the defendant. Both parties resided in Quebec and the automobile was registered and insured in that province. If the accident had taken place in Quebec, the defendant would have been liable for the plaintiff's damages whereas in Ontario at that time drivers and owners could not be liable to a gratuitous passenger. As the Supreme Court found the tortfeasor to have driven in a careless manner in breach of the Ontario Highway Traffic Act, the wrong was not justifiable under the lex loci delicti and the gratuitous passenger was able to recover her damages.

In the arduous task of distinguishing McLean v. Pettigrew from the facts of the case under appeal, the court resorted to a variety of arguments some of which are of a dubious value. First, a review of a number of Canadian decisions which applied McLean v. Pettigrew enabled the Court of Appeal to conclude that this case did not preclude the application of the law of Quebec. Although the court admitted that in the past the residence of the parties may not have been a decisive factor in interpreting the second rule in Phillips v. Eyre, it attached great importance to the fact that in the case under review the two appellants were resident in the place where the accident took place whereas this was not so in McLean v. Pettigrew. Yet, it should be noted that in the latter case, the residence of all the parties in the place where the action was brought may have been the decisive factor in allowing recovery by the gratuitous passenger. The Court of Appeal also relied upon the qualifying clause "[a]s a general rule" used by Willes J. in Phillips v. Eyre in his statement of the rule to point out that it admits of exceptions. Since in McLean v. Pettigrew, Taschereau J. also used the prefatory words "[u]nder these conditions", ${ }^{25}$ there were good reasons for the Court of Appeal in the light of other factors not to interpret his judgment as requiring that the second rule in Phillips $\mathrm{v}$. Eyre be applied in all cases of foreign 
torts, especially if it would lead to an unjust result as in the case under appeal. In McLean v. Pettigrew, the result on the facts was a just one which could also have been reached by applying the doctrine of the proper law of a tort. In the present case the accident took place in Quebec where it was covered by the Quebec automobile compensation scheme. The appellants, as residents of that province, were legally entitled to the protection of that scheme. It would have been unjust to submit them to the law of Ontario and destroy their reasonable expectations of the legal consequences of their conduct ${ }^{26}$ As for the respondent victim, the court stated that it would be difficult to believe that she would have had any reasonable expectation that Ontario law would apply to the exclusion of Quebec law with respect to any driving accident occurring in Quebec. This view, however, emphasizes the place of the accident rather than the residence of the tortfeasor. Finally, the Court of Appeal added that comity as between the provinces required one province when applying its laws not to ignore the policies of another province as expressed in its legislation. Thus, the court concluded that on the facts of the case it should not apply the "punishable" gloss of the second rule in Phillips v. Eyre. Since the appellants were not civilly liable to the respondent for the accident in Quebec, her claim was held to fail. ${ }^{27}$

Today, at least in Ontario, until we hear from the Supreme Court of Canada, where the defendant resides in the place of the tort, 'not justifiable', in Phillips $\mathrm{v}$. Eyre, means the absence of civil liability, in respect of the relevant claim as between the actual parties, of the kind sought to be imposed under that law.

It is interesting to note that the Court of Appeal preferred to distinguish McLean v. Pettigrew rather than to give an entirely new interpretation to the second rule in Phillips v. Eyre. Thus, Machado v. Fontes remains valid in certain cases in order to achieve individual justice. Actually, the decision of the Court of Appeal is a disguised attempt to adopt the doctrine of the proper law of a tort since the application of the test in McLean v. Pettigrew or the one in Grimes v. Cloutier and Cloutier depends upon the existence of certain connecting factors that indicate which jurisdiction has the most significant relationship with the occurrence and the parties with respect to a particular issue. Probably, the court took this approach because it favoured reforming the law by legislative rather than judicial intervention. In view of previous unsuccessful attempts to adopt uniform legislation in Canada in this area of the conflict of laws, ${ }^{28}$ it would be better for the Supreme Court of Canada to discard the rule in McLean v. Pettigrew and to adopt the following one: ${ }^{29}$

26. Note that in Tooker v. Lopez, 24 N.Y. 2d 569 (1969), at 585, the court stated that "when the driver's conduct occurred in the state of his domicile and that state does not cast him in liability for that conduct, he should not be held liable by reason of the fact that liability would be imposed upon him under the tort law of the state of the victim's domicile."

27. For a recent Australian case involving almost similar facts see Breavington v. Godleman, supra, note 12, where the claim also failed and comment by H.P. Glenn (1989) 68 Can. Bar Rev. 584.

28. See Proceedings of the Forty-Eighth Conference of Commissioners on Uniformity of Legislation in Canada (1966) at 62.

29. Based on formulations by Lords Hodson and Wilberforce in Chaplin v. Boys, supra, note 9, at 380. 391. See also Dicey \& Morris, The Conflict of Laws (11th ed., 1987), nule 205, at 1356-66 and Restatement of the Law Second, Conflict of Laws (1971), s. 146. 
As a general rule, an act done in a foreign country is a tort and actionable as such in [Ontario] only if it is actionable as a tort according to [Ontario] law, subject to the condition that civil liability in respect of the relevant claim exists as between the actual parties under the law of the foreign country where the act was done. As an exception, a particular issue between the parties may be governed by the law of the country which, with respect to that issue, has the most significant relationship with the occurrence and the parties.

Such a rule combines the objectives of certainty and flexibility in the interest of individual justice. Had it been applied in Grimes v. Cloutier and Cloutier, the result would have been the same. The exception should be invoked only in special circumstances where, after examination of the policy underlying the law which may be applied and the interests of the parties to be affected, it is clear that the lex loci delicti has no real connection with the proceedings, in order to enable a plaintiff to recover damages available in the lex for $i$ but not available in the lex loci delicti. This requirement should do much to alleviate any fears that unacceptable uncertainty will be introduced in this area of the law. In the case of interprovincial torts, the flexible exception should not be invoked to avoid the application of the law of the province where the wrong occurred especially when the residence of the parties or of the defendant is in that province. To apply some other law, for instance, the lex fori as in Chaplin v. Boys in the name of flexibility would not be conducive to uniform enforceability of liability for torts occurring within Canada.

When Canadian residents travel from one province or territory to another they are conscious of moving from one legal regime to another in the same country and that there may be differences between the two which will impinge in some way on their rights, duties and liabilities. It may come as no surprise to them to find that the local law governs their rights and liabilities in respect of any wrong they did or any wrong they suffered in a province or territory. In these circumstances, there is a stronger case for looking to the lex loci delicti as the governing law for the purpose of determining the substantive rights and liabilities of the parties in respect of a tort committed within Canada. In Grimes v. Cloutier and Cloutier it was appropriate that the Ontario Court of Appeal applied the law of Quebec exclusively. In a federation an individual should not be exposed to the injustice of being subjected to the requirements of contemporaneously valid but inconsistent laws. In the absence of some relevant overriding territorial nexus, one province must not be able to attach legal liability for conduct and consequences which are wholly within the territory of another province, nor can it refuse to recognize or apply the substantive law of that other province in relation to that conduct and its consequences. Interprovincial comity requires such an attitude..$^{30}$

The decision of the Ontario Court of Appeal is welcome. It is creative within its limited scope but as the court itself remarked, in Canada, the entire subject of foreign torts should be "reconsidered from the ground up" . ${ }^{31}$ Let

30. See also W.A. Richardson, "The Rule in Phillips v. Eyre: The Road Not Taken" (1989), 31 C.P.C. (2d) 65 , at $81-82$.

31. At 661 . 
us express the pious hope that this call for reform will be answered soon. ${ }^{32}$ Until then, Machado v. Fontes continues to live on, even if it is limping more and more!

32. In Prefontaine v. Frizzle, Cuddihey v. Robinson (1990), 71 O.R. (2d) 385, the Ontario Court of Appeal extended the scope of Grimes v. Cloutier to bar a claim by Quebec plaintiffs against Ontario resident defendants arising out of accidents in Quebec even though the defendants' acts infringed the Quebec Highway Safety Code, S.Q. 1981, c. 7. The application of the Ontario law was not within the reasonable expectations of the parties. The plaintiffs having received benefits under Quebec law it would be unjust to compensate them again. To do so would also encourage forum shopping. As for the relatives claiming under the Family Law ACt, 1986, they could succeed only if the victim had a right to maintain a claim in Ontario. 